\title{
Opinions and attitudes of Serbian high school students regarding usage of antibiotics
}

Nemanja R. Kutlesic and Dimitrije Milasavljevic

Nemanja Kutlesic

nemanja.kutlesic@studenti.unicam.it

SCHOOL OF BIOSCIENCES AND VETERINARY

MEDICINE, UNIVERSITY OF CAMERINO, ITALY

Manuscript received 18 March 2020; accepted 13 May 2020.

102 | Fine Focus 


\section{Abstract}

Proper usage of antibiotics is a rather important subject that is often overlooked in secondary education, which can provoke misconceptions among youth towards this important topic. The aim of the study was to examine the knowledge and habits regarding the usage of antibiotics in high school population. The research hypothesized that the students would have an acceptable level of basic knowledge on antibiotics and their usage, as students from all study programs are taught equally about antibiotics. The research also examined whether parents' affiliation in healthcare influences their knowledge.

The study has discovered that most of the students have an acceptable knowledge on the matter, with 59\% being acquainted with the antibiotics' mechanism of functioning. The largest part (78\%) was able to distinguish Paracetamol from antibiotics. However, as much as $41 \%$ identified that they have taken antibiotics from different time than prescribed and $31 \%$ admitted to having used antibiotics to treat viruses. A majority have identified their doctor as their source for advice about treatment (67\%).

The research shows that students' knowledge is generally constant among the groups, regardless of the study course or parents' affiliation in healthcare. The only exception is that more students with parents' working in healthcare have taken antibiotics for the time prescribed $(\mathrm{p}<0.05)$.

Overall, students have demonstrated good theoretical knowledge with habits that should be improved. Students need to be better acquainted with guidelines of proper usage through informative campaigns and school projects. 


\section{Introduction}

Clinical effectiveness of antibiotics is directly dependent on the manner of their usage [2, 5, 42]. Any improper, irrational use of antibiotics could lead to the treatment failure, adverse side effects, or development of antimicrobial resistance [5, 13, 19, 20, 40, 42]. According to the World Health Organization (WHO), resistance to antibacterial/viral/parasitic/ fungal drugs occurs when microorganisms change in ways that render the medication used to cure the infections they cause ineffective [39]. During the first 20 years after Fleming's discovery of penicillin (1928), followed by the discovery of several other classes of antibiotics, it seemed that bacteria-induced diseases were defeated. Unfortunately, since then, almost every type of bacterium had developed resistance to one or more antibiotics in clinical use $[3,7,30]$, Escherichia coli, Klebsiella pneumoniae, Staphylococcus aureus, Streptococcus pneumoniae being the most reported [14]. It has been estimated that antimicrobial resistance causes 700000 deaths per year; by 2050 this number may rise to 10000000 deaths per year [29]. Bacterial resistance to antibiotics is a global health emergency [33], since there are more and more infections that become harder or even impossible to treat. As in the pre-antibiotic era, the most common infections and minor injuries could become lethal again $[3,11]$.

Antibiotic misuse can be the consequence of physicians' error, like over-prescription [3]. It can also be associated with consumers' drug use habits and their insufficient/incorrect knowledge of antibiotics indications/contraindications, storage, dosage, possible side effects and duration of therapy $[6,18$, 42]. Taking antibiotics without a prescription (selfmedication), together with over-prescription, leads to increased antibiotic consumption in the community, which has been positively associated with bacterial resistance [7]. The association is particularly strong in South European countries, including Serbia, where antibiotic consumption is higher than in Northern Europe $[7,30]$. Strict guidelines for prescription and antibiotic use resulted in lowest level of resistance in Scandinavian countries, UK, and the Netherlands [4, $18,19,21,36]$. Belief that antibiotics can prevent and cure any disease, that all types of infection (including viral or fungal) should be treated with antibiotics, that they can be effective as antipyretics, antitussics, painkillers, are common misconceptions that lead to the development of antibacterial resistance and, consequently, increased morbidity, duration of treatment, side effects, even premature mortality $[5,6$, $9,10,15,22,23,26,27,31,40]$.

These worrying data related to antibiotics usage have been the motivation for the conduction of this research, which has encompassed a sample of 130 students of different age groups within a Serbian high school located in the country's third-largest city that features a specialized clinical center [38]. The study's main objective was to examine the overall knowledge, beliefs and habits of Serbian high school students from the sample regarding antibiotics usage. The secondary objective of the study was to determine the influence of the study course as well as the students' family background (i.e. if a person engaged in a medical profession is present in the family) on the students' overall knowledge of antibiotics.

Currently, in the high school education program in the country of study, antibiotics are briefly mentioned in the Chemistry course in the fourth year of the course of study as drugs used to treat common infections of bacterial origin (population of 17 to 18 years of age) [34]. At the time of the study, no participants had completed this chapter. Similar cases of only a small part of the curricula devoted to study of antibiotics have been reported in other European countries, such as Portugal [5]. However, the base of Biology courses in Serbian high schools include a 
chapter on Bacteria and Viruses, which also includes parts devoted to usage and functioning mechanism of antibiotics. Information reported in this chapter include the division of bacteria into Gram-positive and Gram-negative species. Some examples of bacterial diseases are cited along with the bacterium that causes it, and a short passage is devoted to the advice about treatment of bacterial diseases, emphasizing the importance of medical guidance. In some textbooks [8], a particularly strong emphasis is put on the fact that antibiotics cannot be used to treat viral diseases. During the course of this study, all the participants have already completed the study of this chapter, as it is studied in the first semester of the first year of high school. Therefore, we hypothesize that Serbian high school population will demonstrate knowledge of clear distinction between the two types of diseases, unlike some comparable groups in the region. In addition, we expect that students will demonstrate an acceptable level of basic knowledge on the matter, which would include basic understanding of mechanism of functioning, dosing regimens and importance of medical advice when antibiotics are used.

The importance of the study lies in the fact that the studied age group represents a sample of a future main antibiotic-consumer population. Assessing their current knowledge helps determine their capacity to use the medication in a way that is acceptable for both them and their future generation. Furthermore, the analyzed data on antibiotics usage undoubtedly examines educational system's attitude towards the very important topic of antibiotics usage. The revealing of possible misconceptions and bad habits regarding the use of antibiotics would enable to update the school curriculum, devise appropriate awareness campaigns and therefore ameliorate the students' knowledge on such an important topic.

\section{Materials and methods}

Prior to any data gathering, the study was approved by the school board of the public high school in Serbia where the study was performed. The main method for gathering data was conducting a questionnaire among the surveyed parties. Students taking part in the survey were between 15 and 18 years of age. In order to comply with legislative norms of the country where the study was performed, all the students under the legal age of 18 were given consent forms for parents to fill in. By signing these forms, parents gave informed consent for their children to participate in the survey by answering the enclosed questionnaire form, and for this information to be processed and studied for research purposes. Students of legal age have signed the consent themselves. Participation in the study was completely voluntary and included no compensation or reward for participating parties.

Participating students were chosen randomly based on the envelope method for each grade of high school. Total number of participants was 130. Class names were inserted in envelopes that were divided into groups in reference to the study course. From each grade and study course, one envelope was chosen, to give a total number of eight surveyed classes. One class was not surveyed due to a low number of students in the class.

Prior to taking the survey, students were asked whether they have ever taken antibiotics, to ensure that students would be able to give answers to the survey. Surveys were answered in a classroom setting. Language of the survey was Serbian.

All the questions referred to the habits of students regarding recent antibiotic usage throughout their 
Table 1. Yes-no questions used in questionnaire

No

Question

Possible

Answer

1. $\quad$ Have you ever taken an antibiotic for a longer or shorter time period than prescribed?

2. Do you consume alcohol when using antibiotics? *

3. Does any member of your family nucleus work in a healthcare institution?

4. Have you ever used antibiotics when a virus causes your disease, such as in case of common flu and cold?

5. Have you ever acquired antibiotics without prescription?

Yes/No

6. After you consume an antibiotic, do you feel calmer?

Yes/No

7.

Is the Paracetamol** antibiotic?

Yes/No

${ }^{*}$ Legal age in Serbia for acquiring both cigarettes and alcohol is 18 years of age. However, it is not uncommon that younger individuals have access to these substances.

** Paracetamol is a commonly used analgesic or antipyretic drug in Serbia, whose USAN is acetaminophen. This drug is commonly marketed in the USA as Tylenol.

Table 2. Assesment of agreement questions

No

Question

Possible Answer

\begin{tabular}{l|ll}
\hline 1. & $\begin{array}{l}\text { I use antibiotics often on a monthly level for repeated treat- } \\
\text { ments. }\end{array}$ & $1-2-3-4-5$ \\
2. & I am well acquainted with antibiotics' method of function. & $1-2-3-4-5$ \\
3. & I often miss my doses when taking an antibiotic. & $1-2-3-4-5$ \\
4. & $\begin{array}{l}\text { Antibiotics can help us with most diseases (headache, fever, } \\
\text { hypertension, flu, etc.) }\end{array}$ & $1-2-3-4-5$ \\
5. & Name all the applicable advisors for your treatment when ill: & Parents in healthcare \\
& & $\begin{array}{l}\text { Parents not in healthcare } \\
\text { Friends } \\
\end{array}$ \\
& & $\begin{array}{l}\text { Media/internet } \\
\text { Official doctor }\end{array}$
\end{tabular}

106 | Fine Focus 
high school studies. The questionnaire distributed among the groups included two main question groups: simple questions requesting Yes/No answers, and questions in which the surveyed individual was to express the level of consent with the phrase given by answering from 1 to 5 on the Likert rating scale, with 5 expressing highest level of agreement. Furthermore, the questionnaire, although fully anonymous, included personal questions that would help process the data among groups for more effective analysis. Design of the questionnaire was based on many previous studies that have encompassed interviewees from different backgrounds $[1,5,9,15,21,29,36$, and 40].

\section{First question group: yes-no answer}

The first question group was designed to be simple in appearance so that quantitative data can be easily obtained. The questions are listed in the Table 1. Questions were designed in a manner so that they can mostly assess multiple points of interest at the same time. Furthermore, the form of the question was laid out in a manner so that it does not in any way resemble a knowledge test, but rather a survey. This was performed so that students do not put much thinking when giving their answer, thus altering the truth in order for their answers to seem more plausible.

\section{Second question group: assessment of agreement - Likert Rating Scale}

In the second group of questions, students were asked to assess how much they agree with a given sentence linked to antibiotics usage. These questions were designed with the same idea as the questions in the group one, with an aim to provide slightly more in-depth information about students' habits about antibiotics' usage. The possible answers were numbered from 1 to 5 , with number representing levels of agreement, such as: 1 - I do not agree at all, 2 - I mostly do not agree, 3 - Unsure/Don't know, 4 - I partially agree, 5 - I agree completely, as per the five-degree Likert rating scale. The questions are enumerated in the Table 2.

\section{Statistical methods}

In order to better assess the results of the questionnaire, all results have been quantified, first represented by the number of students who gave a particular answer to the question, then by percentile, showing the percentage of a particular response in the overall population of students. For the questions where a scale of answers was expected, differently to the simple Yes/No questions, a mode was determined in order to show the most frequently chosen option, similarly to a study conducted on awareness of antibiotics in Norway [36]. In order to determine the statistical importance of data obtained and its connection to the studied factor, a common $\chi^{2}$-test for independence (Chi-squared test) was used where value $\mathrm{p}<0.05$ was considered significant.

\section{Results}

The study was conducted encompassing 130 participants, who have been offered a questionnaire to fill in regarding their habits and knowledge of antibiotics usage. Of 130 participants asked, 128 participants have completed the questionnaire form as they have stated they had previously used antibiotics. As to comply with the legislative norms, all participants aged under 18,72 of them (56\%), provided a parental consent, or a self-signed form if over 18 years of age. The information about the participants of the survey is provided within Table 3. Participants in survey are students of the Science and mathematics study course (62\%), Languages and 
Table 3. The number of surveyed individuals

\begin{tabular}{lcc} 
& $\begin{array}{c}\text { Number of } \\
\text { students }\end{array}$ & $\begin{array}{c}\text { Percentage in } \\
\text { total population }\end{array}$ \\
\hline All surveyed & 128 & $100 \%$ \\
\hline Students with a medical profession present in the family nucleus & 69 & $54 \%$ \\
Students with no medical profession present in the family nucleus & 59 & $46 \%$ \\
\hline Students of the Sciences and mathematics study course & 80 & $62 \%$ \\
Students of the Language and Humanities study course & 43 & $34 \%$ \\
Not affiliated in a distinct study course & 5 & $4 \%$ \\
\end{tabular}

Participants in survey are students' of the Science and mathematics study course (62\%), Languages and Humanities study course (34\%) or not affiliated in any of the two main courses of study (4\%). Overall, the participants of the study are equally distributed in respect to the presence of member of the family affiliated in a medical profession ( $54 \%$ who have compared to $46 \%$ who do not).

108 | Fine Focus 
Figure 1. Answers to Yes-No questions

\begin{tabular}{|c|c|c|c|c|c|c|}
\hline & & & $\begin{array}{r}\text { Answers to } \\
- \text { YES }\end{array}$ & $\begin{array}{l}\text { Yes-No qu } \\
\ltimes \text { NO } \quad \text { No ans }\end{array}$ & $\begin{array}{l}\text { lestions } \\
\text { wer }\end{array}$ & \\
\hline $\begin{array}{l}140 \\
120\end{array}$ & $2 \%$ & $1 \%$ & $1 \%$ & $2 \%$ & $9 \%$ & $4 \%$ \\
\hline 100 & & & & & & \\
\hline 80 & $76 \%$ & $73 \%$ & $67 \%$ & $66 \%$ & & $55 \%$ \\
\hline 60 & & & & & $91 \%$ & \\
\hline 40 & & 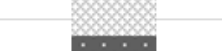 & & & & \\
\hline 20 & $22 \%$ & $26 \%$ & $32 \%$ & $31 \%$ & & $41 \%$ \\
\hline & $\begin{array}{l}\text { Consider the } \\
\text { Paracetamol an } \\
\text { antibiotic }\end{array}$ & $\begin{array}{c}\text { Feel calmer after } \\
\text { a dosage }\end{array}$ & $\begin{array}{c}\text { Acquired } \\
\text { antibiotics with } \\
\text { no prescription }\end{array}$ & $\begin{array}{l}\text { Used antibiotics } \\
\text { to treat viral } \\
\text { diseases }\end{array}$ & $\begin{array}{l}\text { Have not used } \\
\text { alcohol during } \\
\text { the therapy }\end{array}$ & $\begin{array}{l}\text { Have taken } \\
\text { antibiotics for } \\
\text { time different } \\
\text { than prescribed }\end{array}$ \\
\hline
\end{tabular}

Volume Six | 109 
Humanities study course (34\%) or not affiliated in any of the two main courses of study (4\%). Overall, the participants of the study are equally distributed in respect to the presence of member of the family affiliated in a medical profession ( $54 \%$ who have compared to $46 \%$ who do not).

As seen in the Figure 1, most of the participants of the study are aware of the risks of alcohol usage under a therapy including antibiotics (91\%). It is worth noting that of all the participants, 63 (48\%) were of the legal drinking age, which is over 18 . Only $26 \%$ have stated a calming effect of antibiotics. Furthermore, only 22\% have incorrectly classified Paracetamol as antibiotic. However, as much as $31 \%$ have tried to treat viral diseases using antibiotics and as much as $32 \%$ have admitted to acquiring antibiotics without an official prescription. Moreover, $41 \%$ identified to have taken antibiotics for different time than prescribed.

As seen in the Figure 2, only 18 participants (14\%) have admitted to a frequent monthly usage of antibiotics (Mode: 1 - completely disagree). No other question has, however, given such a polarizing answer, where as much as $46 \%(n=59)$ of population expressed doubt towards the regularity of their doses (Mode 2 - Partially disagree). Most of the population claims they are aware of the functioning mechanisms of antibiotics $(59 \%, n=76$, express a high level of certainty (answers 4, 5; mode 4-Partially agree), which is slightly opposed to the given opinions whether the antibiotics can be used against most common everyday diseases, such as headaches, high body temperature, hypertension, flu etc. (mode 3 - Unsure/Don't Know, $38 \%, n=48)$.

Figure 3 represents the answers to the question asking who the participants' choice is when it comes to health and disease treatment advice. For these questions, participants were asked to select all applicable answers, giving a total of 163 answers. The majority of the surveyed population answered Official doctor (86/128 participants or $67 \%)$. The next most frequent answer was Family (69/128 participants or 54\%). Of this number, only slightly more numerous are participants advised by parents not working in healthcare (38/128 participants, $30 \%$ of total population or $55 \%$ within the answer Family). A small number of participants also identified Friends as a source of information and advice ( $2 \%$ of the total population) and Internet or Media (3\% of the total population).

This study also aimed to compare the answers of participants who have and who do not have a family member affiliated to medical profession, as well as answers of participants following different study courses. For a difference in answers to be considered statistically significant the $p$ value must be less than 0.05 . No statistically significant difference has been detected between the groups following different study courses ( $p>0.05$ constantly) and almost no statistically significant difference was discovered between the groups with a different family composition regarding medical professionals. A statistically significant difference was discovered, however $(\mathrm{p}=.045, \mathrm{p}<0.05)$ in answering question about taking the antibiotic for shorter or longer periods than the prescribed time. In the group of students with medical professionals in the family, 23 out of 69 respondents answered that they have done so (35\%), while in the group of students without medical professionals in the family, 30 out of 59 students answered affirmatively (52\%) with a larger obedience to the therapy period detected in the group whose family members are affiliated to the medical industry.

\section{Discussion}

This study aimed to examine the habits of antibiotic 
Figure 2. Answers to questions with assessment of agreement

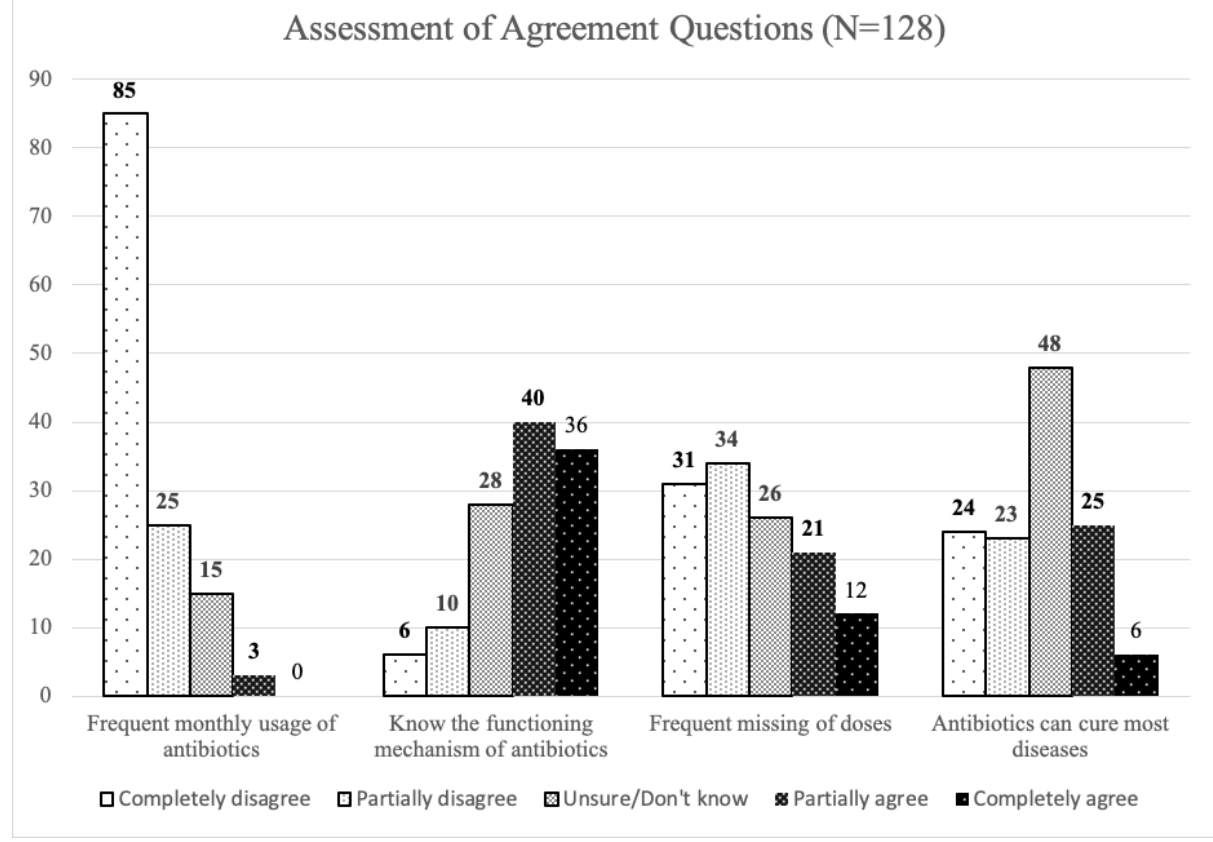

Figure 3. Sources of advice for disease treatment

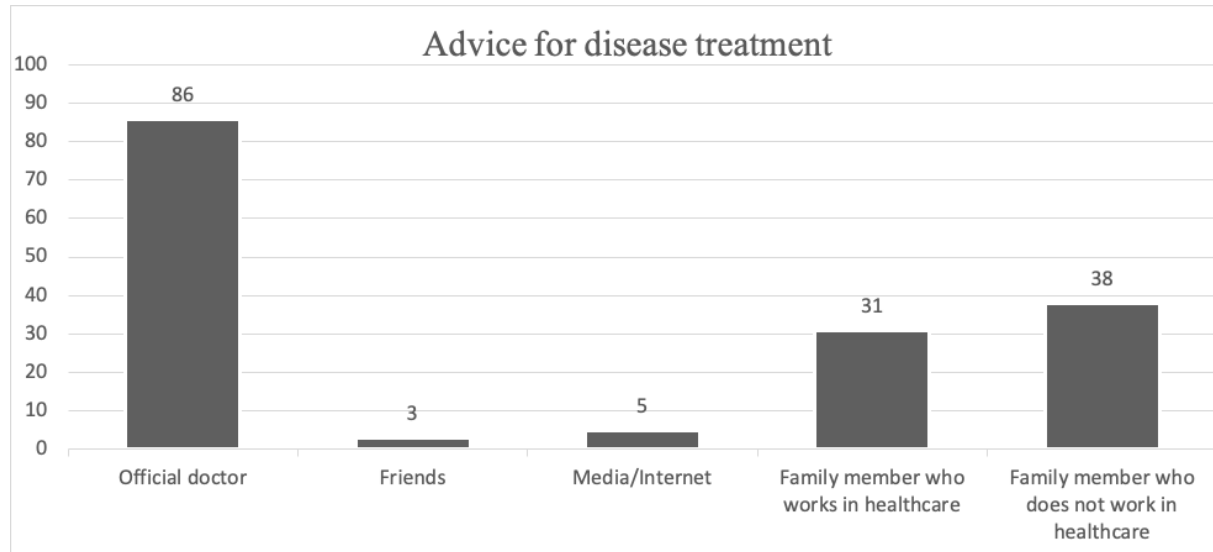

- Advice for disease treatment 
use among students and the knowledge they possess. Furthermore, we wanted to explain the obtained results as well as compare them to similar studies done around the world. Nevertheless, to our knowledge, our study is one of the rare few that bases itself on responses of high-school students [12]. By studying these results, we would be able to observe if there is a widespread problem of misuse and misunderstanding of antibiotics among students that would bring into question the way we currently approach the subject. The results show whether a campaign is necessary to improve students' knowledge on the subject.

The questions were meant to assess: (a) students' knowledge of antibiotics functioning mechanism, (b) students' habits when antibiotics usage is concerned, (c) students' understanding of effects of improper antibiotics usage and (d) students' capacity to distinguish antibiotics from some commonly used medicines. The questions have been designed in compliance with some previous studies in Indonesia [40], Portugal [5], Italy [21] and Oman [15]. The following Table 4 enumerates all the questions in the study with the points that they were meant to assess.

The questionnaire included the usual questions regarding the acquisition of antibiotics, the implementation of a dosing regimen and the usage of alcohol. The question about members of the family nucleus working in health institutions would help assess whether a presence of a medical professional would in any case contribute to a more controlled usage of antibiotics.

Other questions were added in reference to the particular mood regarding usage of medication in Serbia. Being aware of the existence of a belief that antibiotics are extraordinary medicine, able to prevent and cure any disease [40] (representing a "magic bullet”, as put by the famous German Nobel prize winner P. Ehrlich), we wanted to examine whether the students would feel calmer believing the antibiotics are bound to help them cure the disease. In reference to this belief, a question about using antibiotics to treat viral diseases was also added. It has been reported that a common practice exists to use additional selfmedication even after receiving an official prescription from a medical doctor [9, 15, and 40]. A large study encompassing several developing countries by Pechere et al [27] has also reported that antibiotics have been used to treat viral diseases, which generally include common flu and cold. This is why the students were asked if they had used antibiotics to treat a diagnosed viral disease. A similar tendency was observed in a study in Oman [15] and Indonesia [40], where the latter reported a very high rate of $74 \%$ of surveyed parties believing antibiotics are useful in combat against any disease.

Furthermore, the question about Paracetamol was included as this is one of the most commonly used analgoantipyretic drug in Serbia, especially for treating young children. This is one of the medicines that students are most acquainted with from early childhood, and this is why it was important to assess their knowledge on its nature, since some studies reported that antibiotics are being used as antipyretic, antitussives or analgesic drugs $[9,15]$.

Students from Serbia have demonstrated an acceptable knowledge of antibiotics, as seen in Figure 1. This is similar to the studies on the general public in Indonesia [40] and Norway [36], and unlike studies in general public in Kosovo [41] and a study encompassing Chinese university students [37], which has reported a massive cross-country misuse. A majority of students from our sample (73\%) do not report feeling calmer after taking them and do not consume antibiotics on their own (67\%). Of the 
Table 4. Study questions with their points

\begin{tabular}{|c|c|c|c|c|c|}
\hline Statement / Question & Points & Statement / Question & Points & Statement / Question & Points \\
\hline $\begin{array}{l}\text { Does any member of } \\
\text { your family nucleus } \\
\text { work in a healthcare } \\
\text { institution? }\end{array}$ & $\mathrm{A}, \mathrm{C}$ & $\begin{array}{l}\text { Have you ever taken an } \\
\text { antibiotic for a longer or } \\
\text { shorter time period than } \\
\text { prescribed? }\end{array}$ & $\mathrm{A}, \mathrm{B}, \mathrm{C}$ & $\begin{array}{l}\text { Do you consume } \\
\text { alcohol when using } \\
\text { antibiotics? }\end{array}$ & $\mathrm{B}, \mathrm{C}$ \\
\hline $\begin{array}{l}\text { After you consume } \\
\text { an antibiotic, do you } \\
\text { feel calmer? }\end{array}$ & $\mathrm{B}, \mathrm{D}$ & $\begin{array}{l}\text { Have you ever used } \\
\text { antibiotics when a virus } \\
\text { causes your disease, such as } \\
\text { in case of common flu and } \\
\text { cold? }\end{array}$ & A, B & $\begin{array}{l}\text { Have you ever } \\
\text { acquired antibiotics } \\
\text { without prescription? }\end{array}$ & B \\
\hline $\begin{array}{l}\text { I am well acquainted } \\
\text { with antibiotics' } \\
\text { method of function. }\end{array}$ & $\mathrm{A}, \mathrm{C}$ & $\begin{array}{l}\text { Is the Paracetamol an } \\
\text { antibiotic? }\end{array}$ & $\mathrm{D}$ & $\begin{array}{l}\text { I use antibiotics often } \\
\text { on a monthly level. }\end{array}$ & $\mathrm{B}, \mathrm{C}$ \\
\hline $\begin{array}{l}\text { Name all the } \\
\text { applicable advisors } \\
\text { for your treatment } \\
\text { when ill. }\end{array}$ & $\mathrm{B}$ & $\begin{array}{l}\text { I often miss my doses when } \\
\text { taking an antibiotic. }\end{array}$ & $\mathrm{B}$ & $\begin{array}{l}\text { Antibiotics can } \\
\text { help us with most } \\
\text { diseases. }\end{array}$ & $\begin{array}{l}\text { A, C, } \\
\text { D }\end{array}$ \\
\hline
\end{tabular}

Key. A - Students' knowledge on antibiotics' mechanism, B - students' habits on usage, $C$ - students' understanding of effects of improper usage, Dstudents' capacity to distinguish antibiotics from other drugs. 
surveyed students, $78 \%$ were able to differentiate analgoantipyretic Paracetamol - acetaminophen from antibiotics, displaying their knowledge of the most commonly used pharmaceutical drug in Serbia that can be acquired without an official prescription. Among surveyed students, 91\% do not consume alcohol during treatment. A study conducted in a Serbian hospital [16] reported that $90 \%$ of underaged high school students have tried/occasionally used alcohol, with $52.5 \%$ stating that they have consumed alcohol in the 30 days preceding the study. Taking these numbers into account, our results could demonstrate awareness of the effects of alcohol usage during treatment of illnesses. In case of certain antibiotics, these include inhibition of the drug's effect or even violent physical reactions with alcohol [32]. Additionally, alcohol usage in general can cause fatigue, lack of energy, and therefore prolong recovery from the illness, as described by the National Health Service of UK (NHS) [24] and by the Mayo Clinic of USA [35].

In general, these numbers reinforce our hypothesis that students have a good basic knowledge of antibiotic use, as they are aware that antibiotics have no calming or analgoantipyretic effect and that alcohol should not be consumed during treatment.

However, they seem to be less aware of the fact that antibiotics are inefficient in treatment of viral infections since $31 \%$ of them reported that they had used antibiotics to treat viral diseases. This would indicate that, contrary to our hypothesis, a large number of students are still unaware that antibiotics are not helpful against viruses. In addition, a worrying $41 \%$ has reported tampering with the dosing regimen. So, despite their acceptable level of theoretical knowledge, it seems that the students do not apply it to their habits when it comes to consumption of the drugs.

114 | Fine Focus
As seen in the Figure 2, 59\% express a high level of certainty when it comes to understanding the effects of antibiotic usage, similarly to a study conducted in Indonesia [40]. It seems that the most students consider themselves to be well informed about antibiotics and their function. This is in agreement with the result that only $5 \%$ agree completely with the statement that antibiotics cure most diseases. Figure 2 indicates that with only $14 \%$ of students reporting frequent usage of antibiotics on a monthly level, it is safe to assume that the overuse of antibiotics is not a major concern. What should be concerning, however, is the fact that almost a half of surveyed students were not aware of the importance of the adherence to dosing regimens. This coincides with the results of a study performed in China in a similar age group where half of the questioned university students admitted ceasing treatment 1-2 days after clinical improvement, without finishing the full course of treatment [17]. It is worth noting that antibiotics often display the desired effect before the entire treatment is complete, as discussed by Bin Zaman et al [42] in reference to the antibiotic resistance, and it is also highlighted in the guidelines by the NHS [25].

Figure 3 shows that $67 \%$ of students address their family doctor for medication, but $54 \%$ also report that they consult their parents, with no significant difference between those who are and are not affiliated in the healthcare industry. These figures might be explained by students' belief that some everyday ailments are not worth going to the doctor for, and that their family members have enough knowledge and experience to help them. Similar findings were reported in studies done in Turkey [2], Italy [21] and Cameroon [9] while in Kosovo only 0.6\% consulted family members [41]. Furthermore, with friends and media/the internet being reported as $2 \%$ and $3 \%$ respectively, it is clear that students do not consider these sources as relevant when looking for advice concerning treatment. This has reinforced our belief 
that the education and the family nucleus remain as the most prominent sources of knowledge on antibiotics usage of the surveyed students.

The disparity among the answers of students with and without a family nucleus member affiliated in the healthcare industry was insignificant for most questions. The only significant difference found refers to the adherence to dosing regimen. Students who have a family nucleus member in healthcare have reported fewer disruptions of the prescribed regimen, probably because they were warned (by a family member) that in order to obtain the complete effect of the prescribed medication, the full dose must be taken [1].

It is worth noting that no dedicated health class exists in Serbia. Thus, the only knowledge of the subject that the surveyed students could have acquired through their school studies would come from biology classes, where antibiotics are relatively scarcely covered, $[8,34]$. Even though the study course of science-mathematics is oriented towards life sciences and chemistry more than the language-humanities course in terms of time devoted to these subjects, the differences between responses across all questions were minimal. This is likely due to the fact that antibiotics, unlike most topics related to science, are covered equally by the two courses. The subject of bacteria and viruses is studied during first year of biology [8] where the program is identical for both language-humanities and science-mathematics courses. In the time of conducting the study, all the participants had already completed the study of this chapter. Even though the science-mathematics course is geared more towards medicine or pharmacology, these fields are never directly studied based on the official textbook [34].

A group of similar studies on high school students' knowledge on the subject of antibiotics has been conducted in Portugal $[4,5]$, where the topic is covered once during the biology course. The surveyed students from Serbia have demonstrated an overall better level understanding of the subject of antibiotics and their use than their peers despite the overall similar distribution of the topic in the two curricula. Compared to a large study done on university students in China, the surveyed students in Serbia were significantly less likely to buy antibiotics without a prescription $-3 / 10$ compared to $7 / 10$, as well as tending to consult their doctor more often compared to the university students in China [28].

\section{Conclusion}

The results of the study lead to the conclusion that a majority of interviewed high school students understand the basic properties and use of antibiotics. They are able to tell apart the other commonly used analgopyretic Paracetamol from antibiotics and do not consume alcohol during treatment. A majority go to their doctor for advice and prescription. However, many also choose to seek advice from their family, regardless of whether the family member is affiliated with the healthcare industry. The research has shown that a premature interruption of prescribed treatment is common, however it is less frequent among those students whose family is in healthcare as compared to others. Therefore, students need to be better acquainted with the subject through informative campaigns and school projects.

\section{Conflict of interest}

The authors have no conflict of interest to declare. 


\section{Acknowledgments}

The authors thank the following teachers of Svetozar Markovic High School in Nis, Serbia for their work in the distribution of questionnaires and data gathering: Slobodan Petrovic (chemistry) Snezana Mitic (biology) and Dragana Jelenkovic (physics). Also, the authors thank the following students for their efforts in the distribution of questionnaires: Stasa Petrovic, Luka Ilincic (Svetozar Marković High School in Niš, Serbia) and Mila Zivkovic (Faculty of Medicine, University of Niš, Serbia).

116 | Fine Focus 


\section{References}

1. Adorka, M., Kirk, A., Lubbe, M., Serfontein, J. (2013). The impact of healthcare providers' knowledge on appropriate prescription of antibiotics. Journal of Pharmaceutical Care, 1, 133-140.

2. Akici, A., Mollahaliloğlu, S., Dönertaş, B., Özgülcü, Ş., Alkan, A., \& Başaran, N. F. (2017). Patients' attitudes and knowledge about drug use: a survey in Turkish family healthcare centres and state hospitals. Turkish Journal of Medical Sciences, 47, 1472-1481. doi: 10.3906/sag-1608-29

3. Antimicrobial resistance (World Health Organisation). (2019, December 4). Retrieved from https://www. who.int/antimicrobial-resistance/en/.

4. Azevedo, M. M., Pinheiro, C., Yaphe, J., \& Baltazar, F. (2009). Portuguese students' knowledge of antibiotics: a cross-sectional study of secondary school and university students in Braga. BMC Public Health, 9(1). doi: 10.1186/1471-2458-9-359

5. Azevedo, M.-M., Pinheiro, C., Yaphe, J., \& Baltazar, F. (2013). Assessing the impact of a school intervention to promote students' knowledge and practices on correct antibiotic use. International Journal of Environmental Research and Public Health, 10(7), 2920-2931. doi: 10.3390/ijerph10072920

6. Barker, A. K., Brown, K., Ahsan, M., Sengupta, S., \& Safdar, N. (2017). Social determinants of antibiotic misuse: a qualitative study of community members in Haryana, India. BMC Public Health, 17(1). doi: 10.1186/s12889-017-4261-4

7. Bell, B. G., Schellevis, F., Stobberingh, E., Goossens, H., \& Pringle, M. (2014). A systematic review and meta-analysis of the effects of antibiotic consumption on antibiotic resistance. BMC Infectious Diseases, 14(1). doi: 10.1186/1471-2334-14-13

8. Beric, T., Subakov-Simic, G., Janackovic, P. (2014). Biologija za prvi razred gimnazije (Biology for the first grade of grammar school). Belgrade, Serbia: Logos. ISBN: T9788661091742

9. Ekambi, G.-A. E., Ebongue, C. O., Penda, I. C., Nga, E. N., Mpondo, E. M., \& Moukoko, C. E. E. (2019). Knowledge, practices and attitudes on antibiotics use in Cameroon: Self-medication and prescription survey among children, adolescents and adults in private pharmacies. Plos One, 14(2). doi: 10.1371/ journal.pone. 0212875

10. Europeans, science and technology - European Commission. (n.d.). Retrieved from http://ec.europa.eu/ research/press/2001/pr0612en-report.pdf.

11. Fair, R. J., \& Tor, Y. (2014). Antibiotics and bacterial resistance in the 21st century. Perspectives in medicinal chemistry, 6, PMC.S14459. https://doi.org/10.4137/pmc.s14459 
12. Fonseca, M. J., Santos, C. L., Costa, P., Lencastre, L., \& Tavares, F. (2012). Increasing awareness about antibiotic use and resistance: A hands-on project for high school students. PLoS ONE, 7(9). doi: 10.1371/journal.pone.0044699

13. Goossens, H. (2009). Antibiotic consumption and link to resistance. Clinical Microbiology and Infection, 15, 12-15. doi: 10.1111/j.1469-0691.2009.02725.x

14. High levels of antibiotic resistance found worldwide, new data shows. (2018, January 29). Retrieved from https://www.who.int/mediacentre/news/releases/2018/antibiotic-resistance-found/en/.

15. Jose, J., Jimmy, B., Alsabahi, A. G. M. S., \& Sabei, G. A. A. (2013). A study assessing public knowledge, belief and behavior of antibiotic use in an Omani population. Oman Medical Journal, 28(5), 324-330. doi: 10.5001/omj.2013.95

16. Kilibarda, B., Mladenovic, I., \& Rakic-Gudelj, J. (2013). Attitudes on alcohol and drinking patterns among youth in Serbia. Srp Arb Celok Lek, 141(1-2), 66-71. doi: 10.2298/SARH1302066K

17. Lv, B., Zhou, Z., Xu, G., Yang, D., Wu, L., Shen, Q., ... Fang, Y. (2014). Knowledge, attitudes and practices concerning self-medication with antibiotics among university students in western China. Tropical Medicine E' International Health, 19(7), 769-779. doi: 10.1111/tmi.12322

18. Machowska, A., \& Lundborg, C. S. (2018). Drivers of irrational use of antibiotics in Europe. International Journal of Environmental Research and Public Health, 16(1), 27. doi: 10.3390/ijerph16010027

19. McNulty, C., Boyle, P., Nichols, T., Clappison, P., \& Davey, P. (2007). Don't wear me out - the public's knowledge of and attitudes to antibiotic use. Journal of Infection, 55(3). doi: 10.1016/j.jinf.2007.04.019

20. Michael, C. A., Dominey-Howes, D., \& Labbate, M. (2014). The antimicrobial resistance crisis: causes, consequences, and management. Frontiers in Public Health, 2. doi: 10.3389/fpubh.2014.00145

21. Napolitano, F., Izzo, M. T., Giuseppe, G. D., \& Angelillo, I. F. (2013). Public knowledge, attitudes, and experience regarding the use of antibiotics in Italy. PLOS ONE, 8(12). doi: 10.1371/journal. pone. 0084177

22. Naveed, S., Qamar, F., Maqsood, A., Ayub, A., Kauser, H., Malik, H., Fatima, K., \& Hameed, A. (2015). Prevalence and consequences of misuse of antibiotics, survey based study in Karachi. Journal of Bioequivalence E̊ Bioavailability, 07(05). doi: 10.4172/jbb.1000240

23. Nawafleh, H., Momani, M. A., Hadid, L. A., \& Amarat, W. A. (2017). Misuse of antibiotic therapy among university community in South Jordan. Health Science Journal, 10(6). doi: 10.21767/1791809x.1000478

24. NHS: Can I drink alcohol when I am on antibiotics. (2015, May 1). Retrieved from https://www.nhs.uk/

118 | Fine Focus 
common-health-questions/medicines/can-i-drink-alcohol-while-taking-antibiotics/.

25. NHS: Questions over advice to finish course of antibiotics. (2017, July 27). Retrieved from https://www. nhs.uk/news/medication/questions-over-advice-to-finish-courses-of-antibiotics/.

26. Ochoa, C., Eiros, J., Inglada, L., Vallano, A., \& Guerra, L. (2000). Assessment of antibiotic prescription in acute respiratory infections in adults. Journal of Infection, 41(1), 73-83. doi: 10.1053/jinf.2000.0689

27. Pechère, J.-C., Hughes, D., Kardas, P., \& Cornaglia, G. (2007). Non-compliance with antibiotic therapy for acute community infections: a global survey. International Journal of Antimicrobial Agents, 29(3), 245-253. doi: 10.1016/j.jijantimicag.2006.09.026

28. Peng, D., Wang, X., Xu, Y., Sun, C., \& Zhou, X. (2018). Antibiotic misuse among university students in developed and less developed regions of China: a cross-sectional survey. Global Health Action, 11(1), 1496973. doi: $10.1080 / 16549716.2018 .1496973$

29. Pereira, J. Q., Silva, M. T., \& Galvão, T. F. (2018). Use of antibiotics by adults: a populationbased cross-sectional study. Sao Paulo Medical Journal, 136(5), 407-413. doi: 10.1590/15163180.2018 .0168060818

30. Sabuncu, E., David, J., Bernède-Bauduin, C., Pépin, S., Leroy, M., Boëlle, P.-Y., ... Guillemot, D. (2009). Significant reduction of antibiotic Use in the community after a nationwide campaign in France, 2002-2007. PLoS Medicine, 6(6). doi: 10.1371/journal.pmed.1000084

31. Spellberg, B., \& Gilbert, D. N. (2014). The future of antibiotics and resistance: A tribute to a career of leadership by John Bartlett. Clinical Infectious Diseases, 59(suppl 2). doi: 10.1093/cid/ciu392

32. Steckelberg, J. M. (2018, February 6). Can I drink alcohol while taking antibiotics? Retrieved from https:// www.mayoclinic.org/healthy-lifestyle/consumer-health/expert-answers/antibiotics-and-alcohol/faq20057946.

33. The world is running out of antibiotics, WHO report confirms. (n.d.). Retrieved from https://www.who. int/news-room/detail/20-09-2017-the-world-is-running-out-of-antibiotics-who-report-confirms.

34. Velimirovic, S., Petrovic, J. (1994). Hemija za cetvrti razred gimnazije (Chemistry for the fourth grade of grammar school). Belgrade, Serbia: ZUNS. ISBN: 978-86-17-20032-7

35. Ventola, C. L. (2015). The antibiotic resistance crisis part 1: Causes and threats. Pharmacy and Therapeutic, 40 (4), 277-283, PubMed: 25859123

36. Waaseth, M., Adan, A., Røen, I. L., Eriksen, K., Stanojevic, T., Halvorsen, K. H., ... Nordeng, H. M. E. (2019). Knowledge of antibiotics and antibiotic resistance among Norwegian pharmacy customers - a cross-sectional study. BMC Public Health, 19(1). doi: 10.1186/s12889-019-6409-x 
37. Wang, X., Peng, D., Wang, W., Xu, Y., Xudong, Z., Hesketh, T. (2017). Massive misuse of antibiotics by university students in all regions of China: implications for a national policy, International Journal of Antimicrobial Agents, 50 (3), 441-446. doi: 10.1016/j.ijantimicag.2017.04.009.

38. Web presentation of Clinical Centre of Nis, Serbia (2019). Retrieved from http://kcnis.rs/en/.

39. What is antimicrobial resistance? (2017, December 14). Retrieved from https://www.who.int/features/ qa/75/en/.

40. Widayati, A., Suryawati, S., Crespigny, C. D., \& Hiller, J. E. (2012). Knowledge and beliefs about antibiotics among people in Yogyakarta City Indonesia: a cross sectional population-based survey. Antimicrobial Resistance and Infection Control, 1(1), 38. doi: 10.1186/2047-2994-1-38

41. Zajmi, D., Berisha, M., Begolli, I., Hoxha, R., Mehmeti, R., Mulliqi-Osmani, G., ... Raka, L. (2017). Public knowledge, attitudes and practices regarding antibiotic use in Kosovo. Pharmacy Practice, 15(1), 827-827. doi: 10.18549/pharmpract.2017.01.827

42. Zaman, S. B., Hussain, M. A., Nye, R., Mehta, V., Mamun, K. T., \& Hossain, N. (2017). A review on antibiotic resistance: Alarm bells are ringing. Cureus. doi: 10.7759/cureus.1403

120 | Fine Focus 
Volume Six | 121 